Сафонова Надежда Сергеевна, младший научный сотрудник лаборатории иммуногенетики и ДНК-технологий ФГБНУ «Северо-Кавказский федеральный научный аграрный центр» (РФ, 355013, г. Ставрополь, проезд Таврический 3А), тел. 89187507221, e-mail: nadejda2383@yandex.ru

Ковалев Дмитрий Анатольевич, заведущий лабораторией биохимии ФКУЗ Ставропольский противочумный институт Роспотребнадзора (РФ, 355017, г. Ставрополь, ул. Мира, 280, корп. 2, кв. 47) кандидат химических наук, тел. 8(865-2) 26-03-12, e-mail: kovalev_da.stv@list.ru

Ефимова Нина Ивановна, ведущий научный сотрудник отдела овцеводства и козоводства ФГБНУ «Северо-Кавказский федеральный научный аграрный центр» (РФ, г. Ставрополь, ул. Пушкина 30, кв.11) кандидат сельскохозяйственных наук, тел. 8 (8652) 71-95-58, e-mail: smu.sniizhk@yandex.ru

\title{
DOI: 10.32786/2071-9485-2021-04-18 \\ HEMATOLOGICAL PARAMETERS AND RESISTANCE OF THE ORGANISM OF PIGGIES WHEN ADDING AMINO ACIDS AND ENZYMES TO THEIR DIET
}

\author{
O. V. Budtuev, O. D. Budtueva \\ Volgograd State Agrarian University
}

Received 01.03.2021

Submitted 24.11.2021

\section{Summary}

The article deals with the comparative morphological composition of blood, the effect of feeding animals on the composition of the blood, namely the use of threonine and enzyme preparations in the diet of the fattening pigs. This experiment was carried out of on four groups of pigs - control, experimental I, experimental II and experimental III. The diet of the experimental groups was enriched with threonine and enzyme preparations. Comparative analysis of the content of erythrocytes it, leukocytes and the hemoglobin in the blood made it possible to establish that the content of erythrocytes in the experimental groups varied in the range of 6.21-6.29 x 1012/1. It was noted that the control group was inferior to I, II and III in the experimental group.

\begin{abstract}
Introduction. Due to the fact that feed makes up a large part of the total cost of pig production, one of the main ways to solve the problems of the state of production efficiency in the industry is to reduce the cost of feed. The purpose of this study was to collect and analyze data on the use of the amino acid threonine, celloviridin-B G20x and amylosubtilin G3x in fattening young pigs and study their effect on hematological parameters. The main component of pig feed is cereal grain, but it contains an insufficient amount of essential amino acids, in particular threonine. Pigs are monogastric animals, in their digestive tract there are no enzymes that break down complex polysaccharides of plant feed, this, as well as early weaning of animals, encourages the use of enzyme preparations. For this reason, the interest in studying the effect of threonine and enzyme preparations on the physiological parameters of young pigs is currently of interest. Object. The object of this research was young pigs. Materials and methods. Scientific research was carried out at the enterprise, which is the largest pork producer in the Southern Federal District - Joint Stock Company - Cossack Holding Company «Krasnodonskoe», which is located in the Ilovlinsky district of the Volgograd region. aged 112 days, which were divided into 4 groups by the method of analogs pairs (control, I, II, III - experimental), 25 animals each. Results and conclusions. Comparative analysis of the content of erythrocytes, leukocytes and hemoglobin in the blood made it possible to establish that the content of erythrocytes in the experimental groups varied in the range of 6.21-6.29 x 1012 / 1. It was noted that the control group was inferior to the experimental ones in this indicator. An analysis of the hemoglobin content in the blood of young pigs was also carried out and in the II experimental group was $118.07 \mathrm{~g} / 1$, which exceeded the control by $5.67(\mathrm{P}<0.01)$, this analysis made it possible to determine the level of redox processes in the body and analysis of the level of total protein, albumin and globulins in the blood serum of the studied animals, the concentration of total protein in the control group is $79.53 \mathrm{~g} / 1$, which is $4.24 \%$ less than the experimental ones $(\mathrm{P}<0.01), 4.61 \%(\mathrm{P}<0.01)$ and $4.04 \%(\mathrm{P}<0.05)$. The content of albumin in the control group was $34.10 \mathrm{~g} / \mathrm{l}$, which is lower than the experimental ones by $4.78 \%, 7.04 \%(\mathrm{P}<0.05)$ and 5.78\% $(\mathrm{P}<0.05)$, the level of globulins in the control group was $45.43 \mathrm{~g} / 1$, which is lower than
\end{abstract}




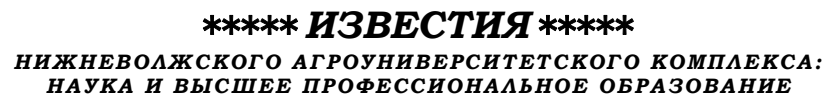

№ 4 (64), 2021

НАУКА И ВЫСШЕЕ ПРОФЕССИОНААЬНОЕ ОБРАЗОВАНИЕ

the experimental ones by $3.83 \%, 2.8 \%$ and $2.64 \%$. Comparative analysis of the content of leukocytes in the blood showed that in the blood of young pigs in the control groups, the content of protective cells was lower by $1.64,1.23$ and $0.49 \%$ than in the blood of young pigs in the experimental groups, but the level of the compared indicators remained within the physiological norm. ... As a result of the research, a beneficial effect of the use of threonine and enzyme preparations in compound feeds of young pigs for fattening on the morphological and biochemical composition of blood was revealed.

Key words: threonine, enzyme preparations, celloviridine-B, amylosubtilin, blood, piggies, hemoglobin, the red blood cells, the white blood cells, morphological composition of blood.

Citation. Budtuev, O. V. Budtueva O.D. Hematological parameters and resistance of the organism of piggies when adding amino acids and enzymes to their diet. Proc. of the Lower Volga Agro-University Comp. 2021.4 (64). 170-178 (in Russian). DOI: 10.32786/2071-9485-2021-04-18.

Author's contribution. All the authors a of this study the participated in the planning, execution, and analysis of the study results. All the authors of this article have read and approved the final version presented.

Conflict of interest. The authors stated that there were no conflicts of interest.

УДК 636.084.1

\title{
ГЕМАТОЛОГИЧЕСКИЕ ПОКАЗАТЕЛИ И РЕЗИСТЕНТНОСТЬ ОРГАНИЗМА ПОДСВИНКОВ ПРИ ДОБАВЛЕНИИ В ИХ РАЦИОН АМИНОКИСЛОТ И ФЕРМЕНТОВ
}

\author{
О. В. Будтуев, кандидат сельскохозяйственных наук \\ О. Д. Будтуева, кандидат сельскохозяйственных наук
}

Волгоградский ГАУ, г. Волгоград, Россия

Дата поступления в редакцию 01.03.2021

Дата принятия к печати 24.11.2021

Актуальность. Себестоимость кормов составляет большую часть от себестоимости общей продукции свиноводства, в связи с этим одним из главных путей решения проблем повышения эффективности производства отрасли является удешевление стоимости кормов. Целью настоящего исследования являлось проведение сбора и анализа данных по применению аминокислоты треонина, целловиридин-В Г20х и амилосубтилина ГЗх при откорме молодняка свиней и исследование их влияния на гематологические показатели. Основным компонентом комбикормов свиней является зерно злаковых культур, однако оно содержит недостаточное количество незаменимых аминокислот, в частности треонина. Свиньи - моногастричные животные, в их пищеварительном тракте нет ферментов, которые расщепляют сложные полисахариды растительного корма. Эта особенность, а также ранний отъем животных побуждают к использованию ферментных препаратов. По этой причине в настоящее время заинтересованность в изучении воздействия треонина и ферментных препаратов на физиологические показатели молодняка свиней представляет интерес. Объект исследования. Объектом данного исследований являлся молодняк свиней. Материалы и методы. Научные исследования проводили на предприятии, являющемся крупнейшим производителем свинины в Южном федеральном округе - АО КХК «Краснодонское», которое находится в Иловлинском районе Волгоградской области, Научный эксперимент проводили на молодняке свиней породы крупная белая, использовали 100 голов молодняка свиней на откорме крупной белой породы в возрасте 112 дней, животных методом пар-аналогов разделили на 4 группы (контрольная, I, II, III - опытные) по 25 голов в каждой. Результаты и выводы. Сравнительный анализ содержания в крови эритроцитов, лейкоцитов и гемоглобина позволил установить, что содержание эритроцитов в подопытных группах варьировалось в диапазоне 6,21-6,29 х $10^{12} / л$. Отмечено, что контрольная группа уступала опытным по данному показателю. Также был проведен анализ содержания гемоглобина в крови молодняка свиней, он составил во II опытной группе - 118,07 г/л, что превышало контрольную на 5,67 $(\mathrm{P}<0,01)$. Данный анализ позволил определить уровень окислительно- 
восстановительных процессов организма и анализ уровня общего белка, альбуминов и глобулинов в сыворотке крови исследуемых животных, концентрация общего белка в контрольной группе - 79,53 г/л, что меньше опытных на 4,24 \% (P<0,01), 4,61 \% $(\mathrm{P}<0,01)$ и 4,04 \% $(\mathrm{P}<0,05)$. Уровень содержания альбуминов контрольной группы составил 34,10 г/л, что ниже опытных на $4,78 \%, 7,04 \%(\mathrm{P}<0,05)$ и $5,78 \%(\mathrm{P}<0,05)$, уровень содержания глобулинов в контрольной группе составил 45,43 г/л, что ниже опытных на 3,83 \%, 2,8 \% и 2,64 \%. Сравнительный анализ содержания в крови лейкоцитов показал, что в крови молодняка свиней контрольной групп содержание защитных клеток было ниже на $1,64,1,23$ и 0,49 \% по сравнению с молодняком свиней опытных групп, однако уровень сравниваемых показателей оставался в границах физиологической нормы. В результате исследований было выявлено благотворное влияние использования треонина и ферментных препаратов в комбикормах молодняка свиней на откорме на морфологический и биохимический состав крови.

Ключевые слова: треонин, ферментные препараты, целловиридин-В Г20х, амилосубтилин, подсвинки, гематологические показатели подсвинков, биохимический состав крови подсвинков.

Цитирование. Будтуев О. В., Будтуева О. Д. Гематологические показатели и резистентность организма подсвинков при добавлении в их рацион аминокислот и ферментов. Известия НВ АУК. 2021. 4(64). 170-178. DOI: 10.32786/2071-9485-2021-04-18.

Авторский вклад. Авторы данного исследования участвовали в организации, выполнении и анализе результатов исследования. Все авторы данной статьи изучили и утвердили представленный итоговый вариант.

Конфликт интересов. Конфликт интересов отсутствовал.

Введение. Добавление в рацион свиней синтетических аминокислот позволит уменьшить конверсию корма, а также снизить уровень токсинов микрофлоры кишечника.

При оптимальном соотношении содержания аминокислот уменьшение уровня сырого протеина в кормах свиней ведет к снижению загрязненности природной среды.

В традиционных рецептах комбикормов в свиноводстве треонин - вторая лимитирующая кислота, основной функцией которой является синтез белка. Кроме этого она участвует в обеспечении физиологических функций системы пищеварения, а именно в образовании муцина и протеинов слизистой оболочки, как следствие выполняет важную функцию в поддержании оптимального течения пищеварительных процессов и нормализации защитной функции ЖКТ [9].

Применение более дешевых кормов в рационах животных и получение при этом высоких результатов позволяет использование ферментов [10].

Ряд зарубежных и отечественных ученых доказали положительное влияние применения ферментных препаратов на использование питательных веществ корма, гематологические показатели и продуктивные качества свиней $[2,3]$.

Переваримость основана на биологических реакциях, в большинстве случаев катализаторами этих реакций являются ферменты.

Цель исследования - изучение морфологического состава крови молодняка свиней, что позволит оценить уровень обменных процессов организма животных.

Объект исследования. В данном исследовании объектом являлся молодняк свиней на откорме.

Свиньи используют из кормового рациона больше половины треонина, в связи с тем что он является составной частью иммуноглобулинов, треонин - важное звено в работе иммунной системы. 
Во время увеличения нагрузки на иммунитет животных большее количество треонина расходуется на образование белков муцина, в результате чего возрастает вероятность возникновения дефицита треонина для роста.

Ферменты - биологически активные вещества органического происхождения, являются катализаторами биохимических реакций, которые возникают в организме животных, а также способствуют расщеплению высокомолекулярных питательных веществ рациона.

Целловиридин В Г20x - продукт микробной культуры Trichoderma reesei, ферментный препарат, который повышает эффективность переваривания клетчатки. Ускоряет метаболизм гомополисахаридов, растительных клеток до моносахаридов. По данным производителя, целловиридин В Г20х увеличивает доступность углеводов, белков и жира для воздействия ферментов желудочно-кишечного тракта; улучшает переваривание и всасывание полезных веществ в тонком отделе кишечника; предотвращает негативное воздействие антипитательных веществ, оказывающих влияние на всасывание; корригирует микробиом кишечника благодаря уменьшению вязкости и увеличению содержания моносахаридов; возмещает недостаток пищеварительных ферментов на первых стадиях развития и во время стресса, когда формирование ферментов собственного организма ограничено.

Использование незаменимой аминокислоты треонин и ферментного препарата целловиридин В Г20х в кормлении свиней позволит скорректировать рацион, улучшить качество мяса и увеличить продуктивность свиней.

Материалы и методы. Эксперимент был проведен в АО КХК «Краснодонское» Иловлинского района Волгоградской области. В научном эксперименте использовали 100 голов молодняка свиней на откорме породы крупная белая, возраст молодняка свиней 112 дней, животных методом пар-аналогов распределили на 4 группы (контрольная, I, II, III - опытные), в каждой группе содержалось по 25 животных. Рационы кормления молодняк свиней были одинаковыми и соответствовали нормам ВИЖ.

Для того чтобы найти оптимальный уровень соотношения треонина, целловиридина-В Г20х и амилосубтилина ГЗх, были подобраны дозы препаратов. Опыт был разделен на три периода: подготовительный, переходный и главный. Исследования крови проводили в главном периоде, в котором свиньям контрольной группы скармливали хозяйственный рацион (комбикорм СК-6, СК-7).

В опытных группах рационы различались содержанием ферментных препаратов. Так, I опытная группа получала хозяйственный рацион и треонин (1,8 кг/т комбикорма), II опытная - хозяйственный рацион, треонин (1,8 кг/т комбикорма) и целловиридин-В Г20х (100 г/т комбикорма), III опытная - хозяйственный рацион треонин (1,8 кг/т комбикорма), целловиридин-В Г20х (100 г/т комбикорма) и амилосубтилина Г3х (300 г/т комбикорма).

Для изучения морфологического состава крови кровь брали из вены хвоста утром в пробирку с трилоном-Б.

Собранные аналитические данные были обработаны статистически с использованием программного обеспечения Microsoft Office Exel, кроме того, был проведен анализ достоверности по статистическим критериям Стьюдента в трех уровнях достоверной вероятности $\mathrm{P}<0,001, \mathrm{P}<0,01$ и $\mathrm{P}<0,05$.

Результаты и обсуждение. Морфологический и биохимический состав крови зависит от полноценного и правильного питания, при выполнении этих условий он постоянен [8].

Количество и качество эритроцитов находится во взаимосвязи с содержанием в крови гемоглобина, уровня обменных процессов, протекающих в организме, эти показатели напрямую влияют на интенсивность роста и развития животных [4]. 


\section{***** Y3BECTYЯ ***** \\ НИЖНЕВОАЖСКОГО АГРОУНИВЕРСИТЕТСКОГО КОМПАЕКСА: \\ НАУКА И ВЫСШЕЕ ПРОФЕССИОНААЬНОЕ ОБРАЗОВАНИЕ}

Как видно из рисунка 1, в результате опыта гематологические показатели крови в опытных группах были выше в сравнении с контрольной на 1,7-4,1 \%.

Уровень гемоглобина в крови молодняка свиней наибольшим был отмечен во II опытной группе, в которой к хозяйственному рациону добавляли треонин и целловиридин - В Г20х, что составило 6,57 г/л.

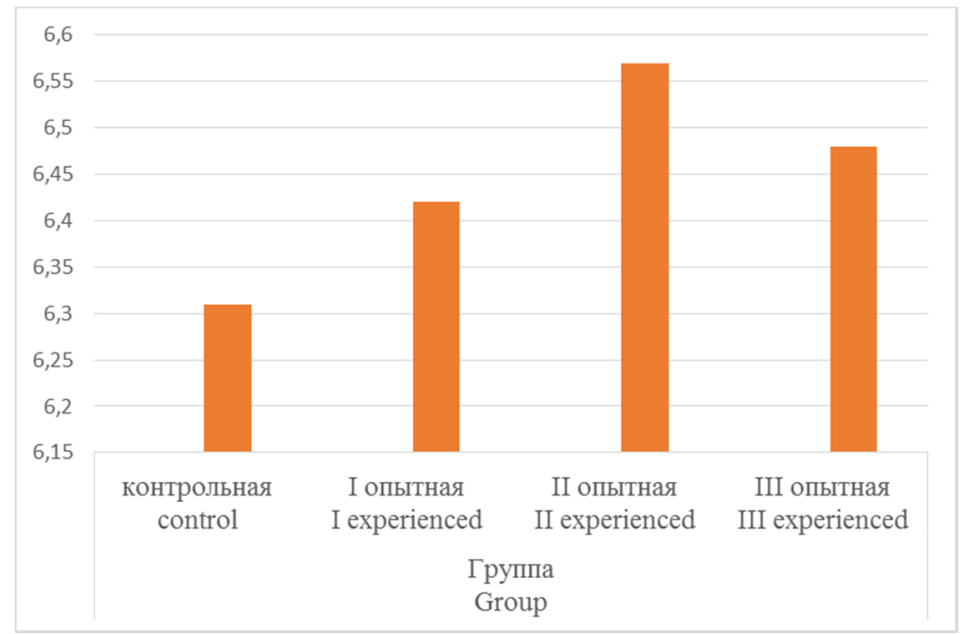

Рисунок 1 - Содержание эритроцитов в крови подопытных подсвинков, $10^{12} /$ л

Figure 1 - The content of a red blood in cells in the blood of the experimental piglets, $10^{12} / 1$

Иммунитет играет роль защитника живых организмов от воздействия вредного воздействия внешней среды, именно благодаря иммунитету организм сохраняет свое биологическое своеобразие и единство.

За иммунный ответ в организме отвечают белые кровяные тельца - лейкоциты, которые различаются по форме и задачам [5].

В крови молодняка свиней объём защитных клеток в контрольной и опытных группах различался: так, опытные группы были выше контрольной на 0,49, 1,23 и 1,64 \% по группам соответственно. Исследуемый показатель оставался в пределах физиологической нормы (рисунок 2).

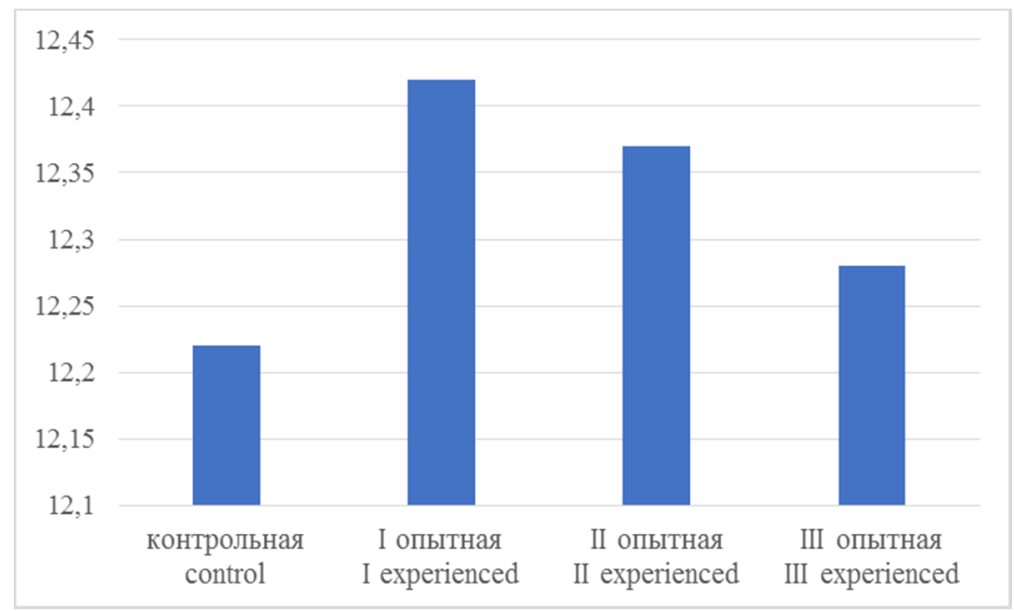

Рисунок 2 - Содержание лейкоцитов в крови подопытных подсвинков, 10 /л

Figure 2 - The content of the white and blood cells in the blood of the experimental piglets, $10^{9} / 1$

На уровень гемоглобина влияет суммарное количество красных кровяных клеток крови [1]. 
Основная функция гемоглобина - перенос кислорода к тканям, выведение углекислого газа и регуляция кислотно-основного состояния организма.

В наших исследованиях уделялось особое внимание данному показателю. Содержание гемоглобина в крови исследуемых животных обусловлено количеством поступившего в организм треонина и ферментных препаратов (рисунок 3 ).

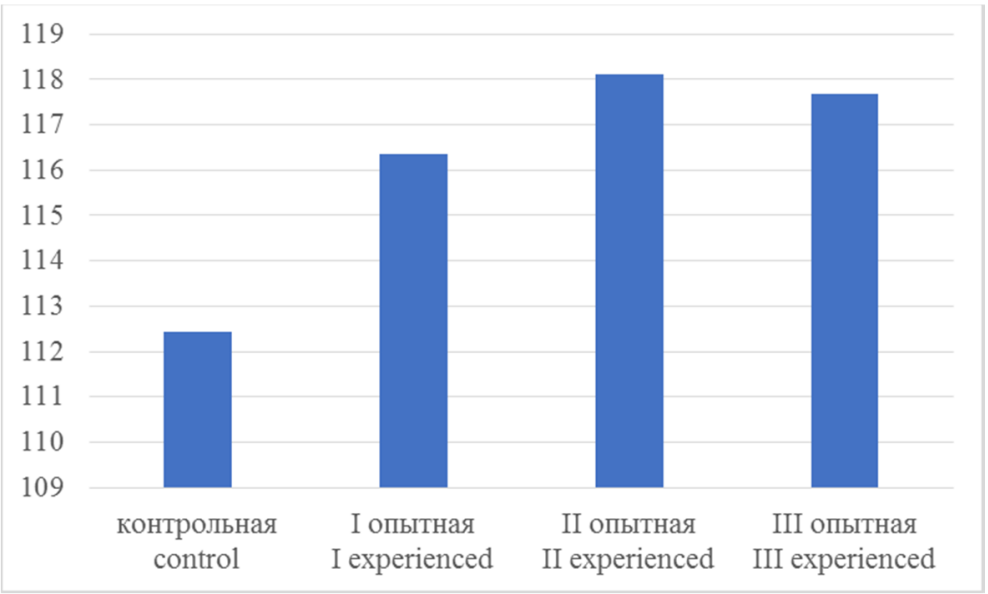

Рисунок 3 - Содержание гемоглобина в крови подопытных подсвинков, г/л

Figure 3-Hemoglobin content in the blood of experimental piglets, g/l

Исследованиями установлено повышение содержания в крови гемоглобина в опытных группах подсвинков, в рационы которых были включены аминокислота треонин и ферментные препараты: целловиридин-В Г20х и амилосубтилин ГЗх.

Результаты анализа показали, что в крови подсвинков контрольной группы содержание гемоглобина составляло 112,44 г/л, что уступало показателям I опытной на 3,93 $(\mathrm{P}<0,05)$, II опытной группы - на 5,67 (P<0,01), III опытной группы - на 5,25 (P<0,05).

Для того чтобы провести оценку уровня белкового метаболизма и функционирования отдельных систем и органов животных, проводят анализ сыворотки крови и плазмы, рассматривают количество общего белка и его фракций [8] (таблица 1).

Таблица 1 - Количество общего белка, альбуминов и глобулинов в крови исследуемых молодняка свиней $(\mathrm{n}=3)(\mathrm{M} \pm \mathrm{m})$

Table 1 - The amount of a total protein, albumins and globulins in the blood of the studied a piglets $(n=3)(M \pm m)$

\begin{tabular}{|c|c|c|c|c|c|c|}
\hline \multirow{2}{*}{$\begin{array}{l}\text { Показатель / } \\
\text { Indicator }\end{array}$} & \multirow{2}{*}{$\begin{array}{c}\text { Общий } \\
\text { белок, г/л / } \\
\text { Total } \\
\text { protein, g / } 1\end{array}$} & \multicolumn{2}{|c|}{$\begin{array}{l}\text { Альбумины, г/л / } \\
\text { Albumins, g / } 1\end{array}$} & \multicolumn{2}{|c|}{$\begin{array}{c}\text { Глобулины, г/л / } \\
\text { Globulins, g / } 1\end{array}$} & \multirow{2}{*}{$\begin{array}{c}\text { А/Г ко- } \\
\text { эффици- } \\
\text { ент / } \\
\text { A / G } \\
\text { coefficien }\end{array}$} \\
\hline & & & $\begin{array}{c}\text { \% к общему } \\
\text { белку / \% of total } \\
\text { protein }\end{array}$ & & $\begin{array}{l}\% \text { к общему } \\
\text { белку / \% of } \\
\text { total protein }\end{array}$ & \\
\hline $\begin{array}{l}\text { Контрольная / } \\
\text { Control }\end{array}$ & $\begin{array}{c}79,53 \pm \\
0,49\end{array}$ & \begin{tabular}{|l|}
$34,10 \pm$ \\
0,50
\end{tabular} & $\begin{array}{c}42,87 \pm \\
0,50\end{array}$ & $\begin{array}{c}45,43 \pm \\
0,41\end{array}$ & $\begin{array}{c}57,13 \pm \\
0,50\end{array}$ & $\begin{array}{c}0,75 \pm \\
0,01\end{array}$ \\
\hline $\begin{array}{l}\text { I опытная группа / } \\
\text { I experimental group }\end{array}$ & $\begin{array}{l}82,90 \pm \\
0,35^{* *}\end{array}$ & \begin{tabular}{|c|}
$35,73 \pm$ \\
0,71 \\
\end{tabular} & $\begin{array}{c}43,10 \pm \\
0,68\end{array}$ & $\begin{array}{c}47,17 \pm \\
0,76 \\
\end{array}$ & $\begin{array}{c}56,90 \pm \\
0,68\end{array}$ & $\begin{array}{c}0,76 \pm \\
0,02\end{array}$ \\
\hline $\begin{array}{l}\text { II опытная группа / } \\
\text { II experimental group }\end{array}$ & $\begin{array}{l}83,20 \pm \\
0,47 * *\end{array}$ & \begin{tabular}{|c|}
$36,50 \pm$ \\
$0,29 *$
\end{tabular} & $\begin{array}{c}43,87 \pm \\
0,29\end{array}$ & $\begin{array}{c}46,70 \pm \\
0,40\end{array}$ & $\begin{array}{c}56,13 \pm \\
0,29\end{array}$ & $\begin{array}{c}0,78 \pm \\
0,01\end{array}$ \\
\hline $\begin{array}{l}\text { III опытная группа / } \\
\text { III experimental group }\end{array}$ & $\begin{array}{c}82,73 \pm \\
0,55^{*}\end{array}$ & \begin{tabular}{|l|}
$36,10 \pm$ \\
$0,46^{*}$
\end{tabular} & $\begin{array}{c}43,63 \pm \\
0,41 \\
\end{array}$ & $\begin{array}{c}46,63 \pm \\
0,38 \\
\end{array}$ & $\begin{array}{c}56,37 \pm \\
0,41 \\
\end{array}$ & $\begin{array}{c}0,77 \pm \\
0,01\end{array}$ \\
\hline
\end{tabular}


Оценка данных таблицы 1 показала, что количество общего белка в крови опытных групп выросло на 4,24 \% (P<0,01), 4,61\% (P<0,01) и 4,02\% $(\mathrm{P}<0,05)$ в сравнении с контрольной группой. Также было отмечено повышение уровня альбуминов на $4,78 \%$, $7,04 \% ;(\mathrm{P}<0,05)$ и $5,87 \%$; $(\mathrm{P}<0,05)$ и глобулинов - на $3,83 \% ; 2,80 \%$ и $2,64 \%$ в опытных группах по сравнению с контрольной группой.

В ходе исследований наблюдалось увеличение количества гемоглобина, лейкоцитов и эритроцитов. Количество общего белка, альбуминов и глобулинов в сыворотке крови также имело тенденцию к увеличению, однако данные показатели не выходили за границы физиологической нормы, что подтверждает возможность применения треонина и ферментных препаратов в кормлении свиней для улучшения их продуктивности.

Выводы. Считаем, что включение в рацион молодняка свиней треонина и ферментных препаратов необходимо для обеспечения оптимального роста, поддержания жизнедеятельности и здоровья животных.

Морфологический и биохимический состав крови молодняка свиней, в рационах которых содержались треонин, целловиридин-В Г20х и амилосубтилина Г3х, отличался более высоким содержанием в периферической крови: эритроцитов - на 1,7-4,1 \%; лейкоцитов - на 0,49-1,64 \%; гемоглобина - на 3,48-5,68 \%; общего белка - на 4,02-4,61 $\%$; альбуминов - на 4,78-7,04 \%; глобулинов - на 2,64-3,83\%.

Изучаемые показатели не выходили за границы физиологической нормы.

Исходя из этого мы делаем вывод, что введение в рацион аминокислоты треонин и ферментных препаратов: целловиридин-В Г20х и амилосубтилин ГЗх оказало положительное влияние на физиологические процессы животных.

\section{Библиографический список}

1. Биохимические показатели крови свиней при оценке качественных характеристик мяса / В. И. Водянников, И. Ф. Горлов, М. И. Сложенкина [и др.] // Свиноводство. 2019. № 1. С. 31-35.

2. Обеспечение потребности свиней в лизине, метионине и треонине с учетом их всасываемости в кишечнике / Е. Н. Головко [и др.] // Сборник научных трудов СКНИИЖ. 2020. № 2. https://cyberleninka.ru/article/n/obespechenie-potrebnosti-sviney-v-lizine-metionine-i-treonine-suchetom-ih-vsasyvaemosti-v-kishechnike.

3. Разработка и использование премиксов в кормлении сельскохозяйственных животных / С. И. Николаев, О. Ю. Брюхно, А. К. Карапетян, М. А. Шерстюгина // Научные основы стратегии развития АПК и сельских территорий в условиях ВТО: материалы Международной научнопрактической конференции, посвященной 70-летию образования ВолГАУ. 2014. С. 200-204.

4. Татаркина Н. И. Использование питательных веществ рационов ремонтным молодняком крупной белой породы свиней // Вестник Курганской ГСХА. 2019. № 2 (30). https://cyberleninka.ru/article/n/ispolzovanie-pitatelnyh-veschestv-ratsionov-remontnym-

molodnyakom-krupnoy-beloy-porody-sviney.

5. Физиологические показатели и резистентность организма баранчиков при скармливании гранулированных экструдированных комбикормов-концентратов / Н. Г. Чамурлиев, А. С. Филатов, А. С. Шперов, Р. Н. Муртазаева, А. Р. Амирханян // Известия Нижневолжского агроуниверситетского комплекса: наука и высшее профессиональное образование. 2018. № 3 (51). C. 247-251.

6. Ходырева И. А. Продуктивные качества и гематологические показатели молодняка свиней при использовании пробиотика «Биохелп» // Актуальные проблемы интенсивного развития животноводства. 2017. № 20 (1). https://cyberleninka.ru/article/n/produktivnye-kachestva-igematologicheskie-pokazateli-molodnyaka-sviney-pri-ispolzovanii-probiotika-biohelp.

7. Шкаленко В. В. Влияние биологически активных кормовых добавок "Лактумин", "Лактофит" и "Лактофлекс" на гематологические показатели молодняка свиней // Известия Нижневолжского агроуниверситетского комплекса: наука и высшее профессиональное образование. 2016. № 2 (42). С. 147-152. 


\section{***** H3BECTYЯ ***** \\ НИЖНЕВОАЖСКОГО АГРОУНИВЕРСИТЕТСКОГО КОМПАЕКСА: \\ НАУКА И ВЫСШЕЕ ПРОФЕССИОНААЬНОЕ ОБРАЗОВАНИЕ}

8. Ao X., Yoo D. H., Kim I. H. Effects of dietary electrolyte balance on reproductive performance and blood profiles in sows // Animal Feed Science and Technology. 2020. Vol. 259. P. 210-218.

9. Effects of dietary gallic acid on growth performance, diarrhea incidence, intestinal morphology, plasma antioxidant indices, and immune response in weaned piglets / L. Cai, Y. P. Li, Z. X. Wei [et al.] // Animal Feed Science and Technology. 2020. Vol. 261. P. 53-64.

10. Effects of dietary glycine selenium nanoparticles on loin quality, tissue selenium retention, and serum antioxidation in finishing pigs / Y. Zheng, W. Dai, X. Hu, Z. Hong // Animal Feed Science and Technology. 2019. Vol. 254. P. 43-45.

Conclusions. We believe that the inclusion of threonine and enzyme preparations in the diet of piglets is necessary to ensure optimal growth, maintain the vital activity and health of animals.

The morphological composition of the blood of piglets whose diets contained threonine, celloviridine-B G20x and amylosubtilin G3x was characterized by a higher content in peripheral blood:

- of red blood cells by 1.7 - to $4.1 \%$;

- white blood cells by $0.49-1.64 \%$;

- hemoglobin at $3.48-5.68 \%$;

- total protein by $4.02-4.61 \%$;

- albumins at 4.78-7.04\%;

- globulins by $2.64-3.83 \%$.

Not all the studied parameters exceeded the limits of the physiological norm.

Based on this, we can conclude that the introduction of the amino acid threonine and the enzyme preparations celloviridin-B G20x and amylosubtilin G3x into the diet had a positive effect on the physiological processes of animals.

\section{References}

1. Biochemical indicators of pig blood in the assessment of the quality characteristics of meat / V. I. Vodyannikov, I. F. Gorlov, M. I. Slozhenkina [et al.] // Pig farming. 2019. No. 1. P. 31-35.

2. Ensuring the needs of pigs in lysine, methionine and threonine taking into account their absorption in the intestine / E. N. Golovko [et al.] // Collection of scientific works of SKNIIZH. 2020. № 2. https://cyberleninka.ru/article/n/obespechenie-potrebnosti-sviney-v-lizine-metionine-i-treonine-suchetom-ih-vsasyvaemosti-v-kishechnike.

3. Development and use of premixes in the feeding of agricultural animals / S. I. Nikolaev, O. Yu. Bryukhno, A. K. Karapetyan, M. A. Sherstyugina // Scientific bases of the strategy for the development of agriculture and rural territories in the WTO: proceedings of the International Scientific and Practical conference dedicated to the 70th anniversary of the formation of VolGAU. 2014. P. 200-204.

4. Tatarkina N. I. The use of nutrients in the diets of repair young animals of a large white breed of pigs // Bulletin of the Kurgan State Agricultural Academy. 2019. No. 2 (30). https://cyberleninka.ru/article/n/ispolzovanie-pitatelnyh-veschestv-ratsionov-remontnymmolodnyakom-krupnoy-beloy-porody-sviney.

5. Physiological parameters and resistance of the rams ' organism during feeding of granulated extruded feed concentrates / N. G. Chamurliev [et al.] // Proceedings of the XVIII agrouniversity complex: science and higher professional education. 2018. No. 3 (51). P. 247-251.

6. Khodyreva I. A. Productive qualities and hematological indicators of young pigs when using probiotic "Biohelp" // Actual problems of intensive development of animal husbandry. 2017. № 20 (1). https://cyberleninka.ru/article/n/produktivnye-kachestva-i-gematologicheskie-pokazateli-molodnyakasviney-pri-ispolzovanii-probiotika-biohelp. 


\title{
***** HЗBECTHЯ ***** \\ НИЖНЕВОАЖСКОГО АГРОУНИВЕРСИТЕТСКОГО КОМПАЕКСА \\ НАУКА И ВЫСШЕЕ ПРОФЕССИОНААЬНОЕ ОБРАЗОВАНИЕ
}

7. Shalenko V. V. Influence of biologically active feed additives "Lactumin", "Lactofit" and "Lactoflex" on the hematological parameters of young pigs // Proceedings of the XVIII agrouniversity complex: science and higher professional education. 2016. No. 2 (42). P. 147-152.

8. Ao X., Yoo D. H., Kim I. H. Effects of dietary electrolyte balance on reproductive performance and blood profiles in sows // Animal Feed Science and Technology. 2020. Vol. 259. P. 210-218.

9. Effects of dietary gallic acid on growth performance, diarrhea incidence, intestinal morphology, plasma antioxidant indices, and immune response in weaned piglets / L. Cai, Y. P. Li, Z. X. Wei [et al.] // Animal Feed Science and Technology. 2020. Vol. 261. P. 53-64.

10. Effects of dietary glycine selenium nanoparticles on loin quality, tissue selenium retention, and serum antioxidation in finishing pigs / Y. Zheng, W. Dai, X. Hu, Z. Hong // Animal Feed Science and Technology. 2019. Vol. 254. P. 43-45.

\section{Author's Information}

Budtuev Oleg Valerievich, Associate Professor of the Department of Veterinary and Sanitary Expertise, Infectious Diseases and Morphology of Volgograd State Agrarian University (Russia, 400002, Volgograd, Universitetskiy pr., 26), Candidate of Agricultural Sciences, ORCID: https: // orcid .org / 0000-0002-56690130 tel.8987-650-57-45, e-mail: olegbudtuev@yandex.ru.

Budtueva Olga Dmitrievna, Associate Professor of the Department of Feeding and Breeding of Agricultural Animals of Volgograd State Agrarian University (Russia, 400002, Volgograd, Universitetsky pr., 26), Candidate of Agricultural Sciences ORCID: https://orcid.org/ 0000-0003-2498-5257, tel. 8 937-701-33-53 e-mail: budtuevaolga@mail.ru.

\section{Информация об авторах}

Будтуев Олег Валерьевич, доцент кафедры «Ветеринарно-санитарная экспертиза, заразные болезни и морфология» Волгоградского государственного аграрного университета (Россия, 400002, г. Волгоград, Университетский пр., д. 26), кандидат сельскохозяйственных наук, ORCID: https://orcid.org/0000-0002-5669-0130 тел. 8 987-650-57-45, e-mail: olegbudtuev@yandex.ru.

Будтуева Ольга Дмитриевна, доцент кафедры «Кормление и разведение сельскохозяйственный животных» Волгоградского государственного аграрного университета (Россия, 400002, г. Волгоград, Университетский пр., д. 26), кандидат сельскохозяйственных наук ORCID: https://orcid.org/0000-0003-2498-5257, тел. 8 937-701-33-53 e-mail: budtuevaolga@mail.ru

\section{EVALUATION OF HOMEOSTASIS PARAMETERS OF CALVES AS ONE OF THE CRITERIA OF THE PHARMACODYNAMIC EFFECTS OF SELENOLINE}

\author{
V.A. Grin, M.P. Semenenko, E.V. Kuzminova \\ Federal State Budget Scientific Institution \\ «Krasnodar Scientific Center for Animal Science and Veterinary Medicine», Krasnodar
}

Received 27.10.2021

Submitted 19.11.2021

\section{Summary}

The article provides data on the use of a new injectable selenium-containing preparation selenoline in calves at the age of 3 months. In the framework of a preclinical pharmacodynamic study, the effect of selenoline on blood homeostasis was studied. It was determined that organic selenium, which is a part of the preparation, had a pronounced effect on a number of morphological and biochemical parameters of blood, acting as a modulator of metabolic processes in the body of animals.

\section{Abstract}

Introduction. The trend in the development of modern domestic animal husbandry, based on the improvement of technological methods of cultivation and operation, ensuring an increase in productivity, a reduction in material costs and veterinary load, is associated with the risks of an increase in the discrepancy between the physiological parameters of a certain type of animals and the available parameters of their feeding and maintenance, which contributes to the development of an imbalance in all metabolic processes of the body and, as a consequence, an increase in 